\title{
HOW PARTIES FARED IN THE 2007 ELECTION \\ A Theoretical Exploration of the Outcome
}

\section{Fako Johnson Likoti}

\author{
Dr Fako Likoti is a Senior Lecturer in the Department of Politics \\ and Administrative Studies at the National University of Lesotho \\ Maseru, Lesotho \\ Tel: +266 22340601 \\ Fax: +266 22340000 \\ e-mail: fakolikoti@yahoo.co.uk
}

\begin{abstract}
Lesotho, like other less developed countries, has embarked on the route to democratisation. As part of this process one of the tests a country must go through is the holding of free and fair elections. Elections have been recognised as one of the most important institutional mechanisms for shaping both political participation and competition. The role of elections in a democracy is but one of its fundamentals, albeit a vital one. Since the 1998 election in Lesotho one party appears to be not only dominating the political landscape but also winning every election. The Lesotho Congress for Democracy (LCD) won the 1998, 2002 and 2007 elections despite the fact that it fragmented twice, giving rise to two parties - the Lesotho Peoples' Congress in September 2001 and the All Basotho Convention in October 2006. In 2007 the LCD formed an election pact with the National Independent Party. In analysing the LCD's repeated success this paper considers four voting models: sociological, party identification, patron-client, and rational choice. While there are various voting models the paper argues that the rational choice model appears to come closest to explaining the LCD's success in 2007. It does not, however, claim that the model provides a definitive answer but attempts to reflect patterns that may reveal some similarities with the model.
\end{abstract}

\section{INTRODUCTION}

Elections are intrinsic to democracy building but do not determine whether or not the country is democratic. The delivery of regular, competitive, free and fair elections in which all political parties compete unhindered in their quest to win 
and form a democratically elected government is one of the standards by which a country's commitment to democracy is judged. In fact, democracy is not possible without political parties; 'political parties constitute an important element of modern government' (Nnoli 1986, p 139). Only political parties are able to form modern governments to translate voters' interests into national policies. It is for this reason that parties compete for power. Similarly, for political parties to 'win elections they must attract support from many different groups in the electorate' (Crewe 1993, p 83). According to Heywood (1997) they normally adopt a broad issue of focus in addressing each of the major government policies. In fact, parties are brought together by a shared political vision and preference.

In contemporary societies parties shape people's thinking and perceptions. They have the capacity to appeal to an ever-widening electorate, with the aim of representing it in Parliament and shaping public policy. It is the goal of each party to broaden its membership and construct a wide electoral base in order to win elections. As representatives of the people, modern political parties such as those in Lesotho

adopt a catch-all strategy and therefore place pragmatism before principle and market research before popular participation. The prevalence of such parties in modern politics gave considerable force to arguments based on rational choice models of political behaviour like those of Joseph Schumpeter and Anthony Downs, which portray politicians as power-seeking creatures who are willing to adopt whatever policies are likely to bring them electoral success.

Heywood 1997, p 232

This description of political process appears to be similar to that adopted by parties in Lesotho during the 2007 election. The parties appear to have followed the approach of Schumpeter and Downs in responding to and articulating the views of their members and voters in general in order to win political power. According to Downs's (1957) thesis, political parties themselves lack power because power resides with the consumers, the voters. He describes the political market as analogous to the economic market. Therefore, in such a political market, 'politicians act essentially as entrepreneurs seeking votes, meaning that parties behave very much like businesses' (Heywood 1997, p 234).

\section{THE CONTEXT}

The 2007 election was won by the LCD, notwithstanding the fact that it had been labelled as a party with a poor service delivery record (Public Eye 10 November 
2006), a factor which forced the All Basotho Convention (ABC) leader to form his own party, thus disassociating himself from the LCD (Public Eye 10 November 2006).

The 2007 election, like the three that preceded it, was conducted in an atmosphere of peace and tranquillity. In fact most observers declared it free and fair. What was worthy of note was the role of the Independent Electoral Commission (IEC) in ensuring that both voters and parties had access to unrestricted information about the election. For the first time since 1993 the IEC appointed a three-man media monitoring panel to facilitate free access for all political parties to the national media. The panel ensured that all parties contesting the election had equal access to the public media as provided for in the national election laws, particularly s $47 \mathrm{~K}(1)$ of the National Assembly Act 1992, which states that '... every political party shall have the right to have the substance of its campaign propaganda reported on news broadcasts of Government-owned national media and in any newspaper in circulation in Lesotho'.

A series of live policy debates on state-controlled radio and television ( 3 and 10 February 2007) among the leaders of the seven major parties, which had nominated more than 40 candidates, was facilitated to provide further coverage to enable eligible voters to understand the manifestos of the different parties, thus enabling them to make informed choices (Santho, Likoti \& Sello 2007). This was particularly important because the 2007 election was a snap election.

The 2007 election was undoubtedly one of the most extraordinary in the recent history of Lesotho. There were four reasons for this.

First, for the first time in the country's political history Lesotho was faced with a snap election as a direct consequence of the fragmentation of the ruling party. The breakaway party, the ABC, left the government of Pakalitha Mosisili with the slimmest of majorities in the 120-member chamber. The ABC was formed with 18 members, all former LCD parliamentarians who had gained access to Parliament through the first-past-the-post (FPTP) electoral system. This floor crossing by the $\mathrm{ABC}$ motivated the governing party, which was left with only 62 members of Parliament, to call the election.

Second, the ABC was led by former Communications Minister Thomas Thabane, who was popularly known in some quarters as 'Mr Delivery'. Thabane was able to generate unprecedented interest among prospective voters and injected 'developmental issues' into the campaign, a new feature in Lesotho politics.

Third, this election provided a rare competitive challenge to the party which had ruled the country for a decade with no credible challenger in evidence. The LCD's hegemony appeared to be facing a determined onslaught from its splinter party, the $\mathrm{ABC}$. 
Finally, the election attracted the poorest voter turnout since 1993. Of a population estimated at 2,2-million 916230 registered but fewer than half the registered voters cast their ballots at the 2552 polling stations around the country. Furthermore, only 14 of the 19 political parties that had registered with the IEC contested the election, a clear indication that it was not only the voters who were apathetic, even the parties lacked interest.

To the consternation of opinion pollsters like Work for Justice and Public Eye, who, throughout the campaign, had forecast an $A B C$ victory over the $L C D$, their predictions were proved wrong. The LCD secured 61 seats and its alliance partner, the NIP, won 21 proportional seats - a total of 82 . The LCD / NIP alliance accounted for 68,9 per cent of the National Assembly while the $\mathrm{ABC}$ and its coalition partner, the Lesotho Workers' Party (LWP), won 17 constituencies. The LWP won 10 proportional representation (PR) seats, giving it a total of 27. The Basotho National Party (BNP), a traditional rival of the LCD, emerged fifth, with a poor showing of three PR seats.

Why do voters continue to vote for the LCD? Theories of voting behaviour might give us the answer. Table 1 illustrates the scale of the LCD's victory in three elections.

There are many theories to explain such phenomena. One of them is the sociological model, which emphasises the voting patterns of social groups. The party identification model stresses an individual's psychological attachment to his or her environment. The patron-client model posits that in emerging democracies such as that in Lesotho voters' choices are based more on patronclient power relations than on policy preferences. Finally, the rational choice model argues that voters are rational and vote according to their preferences (Denver 1989; Denver \& Hands 1992; Dunleavy1990; Miller 1990). It is this model on which the paper will focus in analysing the LCD's 2007 victory.

The sociological model stresses that 'social groups will vote for the party that serves their interests' (Dunleavy 1990, p 46). The model argues that individuals' decisions do not reflect their personal choices but the interests of the group of which they are members. Therefore, they vote for the party they believe represents their class interests (Crewe 1993).

Lesotho's electorate lacks this voting consciousness. Basotho vote as party supporters not on the basis of class or groups and their votes, in most cases, reflect individual interests not those of groups or classes, as the model posits. In fact, even during campaigning, voters are mobilised not as blocks but as people who exercise their individual choices.

As far as voting on the basis of group interests is concerned, it can be argued that 'different social groups have different interests and hence different needs' (Denver 1989, p 26). Nonetheless, the model fails to explain deviant voters, who, 
Table 1

The 1998, 2002 and 2007 General Elections

\begin{tabular}{|c|c|c|c|c|}
\hline Year & Main parties & No of votes & $\%$ of votes & No of seats \\
\hline \multirow[t]{4}{*}{1998} & LCD & 355049 & 60,7 & 79 \\
\hline & BNP & 143073 & 24,5 & 1 \\
\hline & $\mathrm{BCP}$ & 61793 & 10,5 & 0 \\
\hline & MFP & 7460 & 1,3 & 0 \\
\hline Total & & 567375 & $100^{*}$ & 80 \\
\hline \multirow[t]{10}{*}{2002} & LCD & 304316 & 54,8 & 77 \\
\hline & BNP & 124234 & 22,4 & 21 \\
\hline & LPC & 32046 & 5,8 & 5 \\
\hline & NIP & 30346 & 5,5 & 5 \\
\hline & BAC & 16095 & 2,9 & 3 \\
\hline & $\mathrm{BCP}$ & 14548 & 2,7 & 3 \\
\hline & LWP & 7788 & 1,4 & 1 \\
\hline & MFP & 6890 & 1,2 & 1 \\
\hline & PFD & 6330 & 1,1 & 1 \\
\hline & NPP & 3985 & 0,7 & 1 \\
\hline Total & & 546644 & $100^{*}$ & 118 \\
\hline \multirow[t]{10}{*}{2007} & LCD/NIP & 229602 & 68,9 & 82 \\
\hline & $\mathrm{ABC} / \mathrm{LWP}$ & 107463 & 22,7 & 27 \\
\hline & BNP & 29965 & 2,5 & 3 \\
\hline & АCP & 20263 & 1,7 & 2 \\
\hline & PFD & 15477 & 0,8 & 1 \\
\hline & ВСР & 9823 & 0,8 & 1 \\
\hline & MFP & 9129 & 0,8 & 1 \\
\hline & BDNP & 8783 & 0,8 & 1 \\
\hline & BBDP & 8474 & 0,8 & 1 \\
\hline & NLFP & 3984 & 0,0 & 0 \\
\hline Total & & 442963 & $100^{*}$ & 119 \\
\hline
\end{tabular}

Source: Independent Electoral Commission

${ }^{*}$ Figures rounded up 
in some cases, form large minorities but fail to form a group. This model 'tends to give the impression that party choice is a sort of spontaneous effect or social location and ignores the active role that political parties play in mobilising and structuring the electorate' (Denver 1989, p 26).

As a low-income country without a solid industrial base Lesotho cannot be classified as class-based, as can highly industrialised countries such as Britain, whose political parties have class-based support. Denver (1989) argues that in Britain the Labour Party, in particular, has been said to draw its support from public sector workers who will vote for it at all costs. Furthermore, the middleclass public sector is less pro-Conservative than the rest of the middle class.

Voting has been associated with social and political factors. Social groups are based on sex, region, religion, class, and industrial sector. The voting patterns in Lesotho are a mixture of these factors and cannot be identified solely with one factor as in Britain, where black and white people can be identified with a certain party or with a particular region or religion. Religion does not feature at all in Lesotho voting patterns. If it did, the BNP would win since it has Catholic inclinations and the majority of Christians in Lesotho are Catholics. Therefore, the model falls short of explaining why the LCD won the election.

The party identification model refers to the psychological attachment voters develop in their early years. The model stresses the importance of long-term factors in determining party identification and the fact that 'the social position that an individual occupies affects the kinds of influence he or she will encounter in interacting with family friends, neighbours, work mates and so on' (Dunleavy \& Husbands 1985, p 4).

These long-term associations are decisive in determining how an individual votes and identifies with a particular party and such environmental pressures are seen more 'in a heavily class-structured society, the schooling of children and the sort of people who become their friends also exert a strong influence'(Dunleavy 1985, p 4).

In a developing country like Lesotho the electorate is not heavily classstructured so the model does not provide an accurate assessment of election outcomes. While party identification is a factor other factors - such as the personality cults of Ntsu Mokhehle (LCD) and Leabua Jonathan (BNP) (Matlosa 1999) - can be said to explain voting patterns.

Furthermore, voting and party identification do not always converge. While most voters identify with their party this does not mean that they do not, on occasion, vote for another party. In Lesotho, for instance, a BNP supporter living in a constituency in which the party has no realistic chance of winning might decide to vote $\mathrm{ABC}$ while remaining a BNP supporter. Party identification does not offer much insight into why the LCD won the 2007 election. 


\section{THE PATRON-CLIENT RELATIONSHIP MODEL}

The system of patron-client relationship according to Randall \& Theobald (1985) is one of a social relationship outside kinship. It emerges once the kinship fails to deliver the necessities of existence such as social protection and security, among others, mostly in agrarian societies like Lesotho. It is therefore an exchange between a superior patron or patron group and an inferior client or client group. In most developing countries, and especially in Africa, the ruling party acts as a patron and voters become an inferior group voting in expectation of some rewards from the patron (ruling party). Developments in these countries depend on patronclient relationships.

Once established the patron-client relationship is perpetuated over time by adding more favours until the client is obligated to the patron for life and even over generations. This relationship occurs 'in societies where the state is underdeveloped, where state institutions are virtually non-existent at the village level so that there is a marked gap between centre and periphery' (Randall \& Theobald 1985, p 54). This situation obtains in Lesotho in some respects, particularly in the far rural areas of the country when the clients have no choice but to bind themselves to a patron as the only means of articulating their interests.

In agreeing with Randall \& Theobald, Barkan (1995) argues that, in agrarian societies, people live close to each other, are attached to the place where they live, love their neighbours, and tend to vote for the same party. This pattern is similar to that in Lesotho because most rural voters, since the birth of the LCD in 1997, appear to have voted for that party, voting for the patron regardless of whether the patron's policies were good or bad (Barkan 1995). Rural voters, therefore, vote for parties and candidates who have provided service to their constituencies or who have the potential to provide constituency services after elections. According to Barkan (1995, p 107), when these communities vote

... they focus on the basic needs of their local community and surrounding region - whether they have adequate water, schools, and health-care facilities, whether there is a farm-to-market road, whether the producer price for the agricultural commodity grown in the area yields a fair return to local farmers, and so on. Inhabitants of a particular rural area usually have a common set of political interests, and they vote accordingly. This explains the high geographic concentration of the vote for competing parties in the recent round of multiparty elections in Africa.

Most rural voters in Lesotho appear to vote in a similar pattern to that described 
above. With the introduction of free education and old-age pensions the level of rural communities' dependence on state-sponsored patronage appears to be overwhelming. Therefore, the ruling party and its members of Parliament (MPs) become patrons who provide practical assistance to the rural population. While these policies fall within the area of social protection to assist the poor, they may also be described as a patron-client relationship and explain why, in Lesotho, rural communities tend to vote overwhelmingly for the same party.

Weingrod (1968) describes patron-client relationship as a process whereby political leaders distribute rewards and other resources in exchange for the vote. In the USA this phenomenon is known as machine politics, with public service jobs given to clients in exchange for votes (Randall \& Theobald 1985). This voting pattern explains the high concentration of votes for specific parties.

The LCD's victories were, however, not confined to the rural areas - city dwellers, too, benefit from pensions and free education so, while the LCD lost 17 constituencies in urban areas it won in others, indicating that while the theory of patron-client relationships, while explaining the voting patterns of rural voters and accounting for the LCD victory, falls short of a complete explanation of why it did not win in all constituencies. It is necessary to look at further possibilities.

\section{RATIONAL CHOICE THEORY}

The rational choice model (RCM) goes under various names, such as 'issue voting model', 'value model', 'prospective model' (where votes are cast with respect to a party's policies for the future), 'retrospective model' (where votes are cast with respect to a government's record) and 'leader personality model' (Miller 1990, $\mathrm{p}$ 53). RCM is the dominant theoretical paradigm in microeconomics. It is also central to contemporary political-science thinking. In recent years the theory has increasingly been used with reference to sociology and other academic disciplines besides economics. The theory has had a far-reaching impact on the study of political science, especially with relation to interest groups, elections, the behaviour of legislatures, coalitions, and bureaucracy, offering as it does a framework for understanding and often modelling the political (social), and economic behaviour of individuals (Dunleavy 1991).

Proponents of RCM do not claim that any model's assumptions are a full description of reality, only that good models can aid reasoning and help formulate falsifiable hypotheses, whether intuitive or not. Successful hypotheses are those that survive empirical tests (Dunleavy 1991).

It is in this context that the RCM is used in this paper to analyse the LCD's 2007 election victory. While models of rational choice are diverse they have one thing in common - they all assume that individuals choose the best action in the 
light of the constraints they face. The model assumes that, given a range of choices, the voter will exercise his or hers to ensure that he or she will derive the maximum benefit.

Anthony Downs (1957), in his celebrated work, An Economic Theory of Democracy, argues that parties are political firms in the business of selling packages of policies in order to maximise votes so as to win and enjoy the fruits of government office. On the other hand, voters are political consumers who use their votes as currency to purchase the public policies on offer during a general election. Many of them are not tied to any party but are rational, free thinking, and determined to gain the maximum return by electing the party that offers them the best policy package at the lowest tax cost. As will become clear in this paper, those rural voters in 61 of 80 constituencies who elected the LCD in 2007 probably did so on the basis cited above.

The RCM applies the same assumptions as are used by economists to analyse voting behaviour. The model argues that a consumer 'operating in an economic market has a finely divisible stock of money to distribute over a wide variety of goods in order to express his or her preferences in a sophisticated and gradual way' (Dunleavy 1985, p 12). The consumer has only one vote to spend on the party that comes closest to providing his needs and, for this, he or she buys a basket of policies. The model does not address the question of how voters reach their decisions but focuses on their attitudes and choices. It claims that '[v]oters make up their own minds about issues, performance and personalities and then vote for the party that comes closest to delivering the policies and performance they want' (Dunleavy 1990, p 53). The voters individually act rationally when choosing to vote for a particular party and use their vote to derive the maximum benefits.

Voters have a clear knowledge of a party's record and 'are as volatile as shoppers choosing between supermarkets, constantly in search of a better product' (Crewe 1993, p 110). They have an enormous amount of information at their disposal, which provides them with various options and helps them reach their decision. Therefore, 'after comparing parties with their own preferred outcomes, they [voters] choose the party closest to their preferences' (Dunleavy 1985, p 13). The rational voters' views are clearly consistent with political issues. They know roughly what options are available and choose the ones that best suit them. They are, according to this model, egotistical and entirely self-interested.

\section{THE LCD'S CAMPAIGN APPROACH}

It appears that the key to the LCD's success is the party's ability to convince sufficient voters that both its pension and education policies, especially free 
education, depend on the incumbent government remaining in office. According to Work for Justice (2006) the government of Lesotho in 2004 introduced an oldage pension of M150 a month for people over 70, the bulk of whom live in rural areas. This pension scheme became a campaign tool in the party's 2007 election campaign (LCD Election Manifesto 2007). Elderly voters were also promised an increase of M50 a month if they re-elected the LCD. The manifesto claimed the party valued the elderly greatly for their wisdom and insight. The party promised to consider ways of improving facilities at pay points in order to facilitate access (LCD Election Manifesto 2007). It can be assumed that, for that reason, most rural people voted according to their economic interests.

Most of the beneficiaries of the pension scheme have not contributed to it and have never worked for government, while those who have, retired civil servants, are not entitled to the pension. The scheme has succeeded in raising individual expectations, a factor that played a large part in the LCD's electoral success. Clearly, as King et al argue, 'one way in which this pocket-book effect is manifested, is through the level of optimism that people exhibit about their financial prospects' (King, Norton, Denver, Seyd \& Crese 1992, p177). The critical question, of course, is how far these changes in individual economic expectation have affected the popularity of the LCD government. There are certainly good reasons for supposing that they may have done so.

In assessing the RCM in relation to the 2007 election it became evident that there was an emerging pattern in support of the model among different groups. The LCD's pension policy won over many voters. Aided by sympathetic national radio station like MoAfrica FM and Radio Lesotho, the party made pensions a major issue. Its success in doing so bears out those RCM theorists who 'draw attention to the significance of issue voting and argue that issues do matter precisely because policy preferences determine the direction of vote choice and not the other way around' (Dearlove \& Saunders 2000, p 164).

Many studies of the relationship between economics and political support have distinguished between 'sociotropic' and 'egocentric' motivations. According to Sanders (1993, p 179), 'voters act sociotropically to the extent that their political judgement depends on their assessment of whether the government's economic performance has been good or bad for the country as a whole'. According to the $\mathrm{RCM}$ voters are prepared to re-elect a government if they feel that it manages the economy in such a way that their future and their children future will be bright.

The pension promise, along with the fact that inflation was maintained at 5 per cent and anticipated economic growth during the following fiscal years was estimated at 3,5 per cent (Public Eye 23 February 2007), appears to have overridden the governing party's failure to deliver on promises of job creation, economic growth, and success in the battle against HIV / AIDS (ABC Manifesto 2006). 
The message was clear: 'I feel good about my own prospects, therefore, I feel good about the LCD government, irrespective of what other parties have been saying.' It was primarily for economic reasons that the voters rewarded the party in power with their votes, perceiving it as better able than its opponents to manage the economy and produce economic prosperity, a sense of well-being, and the feel-good factor.

Former British Labour Party Prime Minister Harold Wilson argued in 1968 that 'all political history shows that the standing of the government and its ability to hold the confidence of the electorate at a general election depends on the success of its economic policy' (Dearlove \& Saunders 2000, p 168). The LCD appears to have done just that.

Another reason for the LCD's success in 2007 was its promise to extend the policy of free education, which had been phased in for primary schools since 2000, to secondary schools, and to provide books for students from poor backgrounds (LCD Election Manifesto 2007). It also promised to allocate M88,4-million to finance activities in the education sector, including provision of infrastructure for the 2007 financial year (Thahane 2007).

The defining feature of rational choice theory is that people try to maximize their interests when it comes to voting or volunteering to serve a particular party. The approach has many variants. Decision theory, for example, centres on costbenefit calculations that individuals make, without reference to anyone else's plans. It may be assumed, perhaps correctly, that voters base their decisions on costbenefit analyses.

In Britain in the early 1990s it was found that 'voters would support the party that would put most money into their pockets. This notion of pocketbook voting, or economic voting, is a more closely specified version of issue voting' (Dearlove \& Saunders 2000, p 167). The rural voters in Lesotho made much the same decisions, thus it can be argued strongly that RCM was very much at work in Lesotho prior to the 2007 election, with voters believing the LCD would 'put most money into their pockets'.

Among the other achievements of which the LCD government boasted during the election campaign were: it had entrenched democracy, empowered women in local government, helped to introduce 10 private radio and television stations, built rural roads and created 30000 new jobs in the past five years (LCD Election Manifesto 2007). The party also agued that in recent years garment manufacturing had been the key driver of growth, recording growth of 53 per cent in 2001 and maintaining this pace until 2004, before stalling in 2005 as a result of strong competition from Asia and the appreciation of the rand/loti (Thahane 2007).

Government took steps to counteract the loss of jobs. Specifically, in order to improve the financial position of firms a supportive tax regime was introduced in 
2006 / 2007 (LCD Election Manifesto 2007). This move, on its own, indicated that the government's economic management strategy was improving, giving voters cause for optimism about their future economic well-being. In-house training was also introduced to bolster employee productivity.

The LCD also pointed to its foreign-policy successes, although this was not a major campaign issue. Lesotho is currently chair of the Southern African Development Community (SADC), has sent both police and military observers to Darfur, Sudan, and is a member of the African Union Security Committee. The prime minister is on record as pointing out that his party has brought peace and stability to the country (LCD Election Manifesto 2007).

As chair of the SADC region Lesotho is driving a process of scaling up regional economic integration. In less than a year SADC will launch a free-trade area (FTA), within which member states will trade with each other duty-free and quota-free. This will raise significantly intra-SADC trade, which now stands at about 25 per cent. With a population of more than 235 million this would present Lesotho with a huge market that would drive its economic growth rate to a sustainable 7 per cent a year (LCD Election Manifesto 2007).

These were some of the associated factors which might have assisted the party, although they did not feature prominently during the campaign. This paper therefore, is an attempt to understand why the LCD has won so many elections (1998, 2002 and 2007) despite noticeable political challenges in the country.

\section{EXPLANATORY FACTORS FOR THE LCD'S ELECTORAL TRIUMPH}

The LCD's success was achieved in most unfavourable circumstances.

First, Lesotho was in a grip of the highest unemployment rate since the early 1980s. The ABC manifesto argued that unemployment was rampant, standing at 45 percent; that there was a high degree of high child labour; that 50 per cent of the population live below the poverty line; and that the United Nations has described 40 per cent of the population as ultra poor, meaning that they cannot afford food (ABC 2007, p 5). The Minister of Finance in his 2007 budget speech corroborated the $\mathrm{ABC}^{\prime}$ s claim that the country was facing an economic catastrophe of major proportions.

this unprecedented deterioration in the land and its people has ushered in a crisis in the social and moral fabric of our society. Unemployment is high, and poverty is deepening; stock theft and armed robbery have become the order of the day; corruption and nepotism are spreading like a cancer in our institutions; and there is 
no doubt that life is becoming harder by the day for an increasing number of our people.

Thahane 2007, p 3

Furthermore, traditional sources of household income - agriculture, and migrant work - have been declining. Migrant labour declined from 126000 in 1987 to 52000 at the end of 2006. Prospects for agriculture as a high-yielding enterprise are threatened by drought and climate change (Thahane 2007). In fact, Lesotho, according to the finance minister, has been losing the global race for jobs, high, broad-based and sustainable economic growth, and poverty eradication to other countries within the Southern African Customs Union (SACU), SADC, Africa and Asia (Thahane 2007). Despite these economic hardships, the LCD won the election.

Second, the prime minister had earlier castigated civil servants for not being loyal to the government, saying they appeared to be attending opposition party rallies (Public Eye 27 March 2006, p 10). He made this statement despite the fact that there is no way of ascertaining whether or not public servants had voted for him in the 2002 election. His outburst was precipitated by concerns that the government was not delivering services. The civil servants were, therefore, singled out as scapegoats for government's failure to deliver (ABC 2007).

The third hurdle faced by the government was that it had earlier introduced what many consider its most unpopular policy, intended to benefit ministers and senior government officials (Public Eye 23 February 2006, p 2). This policy allowed government ministers to purchase Mercedes Benz luxury cars for M4 000 and Toyota Camrys for civil servants in statutory position for M2 000 (Government of Lesotho 2006) - the vehicles were previously leased to the government by a fleet services company and were supposed to be sold to officials after three years. The vehicle scheme furore appears to have left a legacy of resentment among a large proportion of urban voters, something that can be deduced from the fact that for the first time since the LCD had come to power it lost most constituencies in the capital, Maseru.

Subsequent to the outcry over the vehicles, in August 2006 the government dispatched a group of senior ministers to national television to defend the decision as legitimate government policy, insisting that the benefits that went to 26 ministers were meagre in comparison with world standards. In Lesotho, with its small economy and with economic growth (real GDP growth) of 4,5 per cent for 2006 (FAO 2007) and nowhere near reaching its macroeconomic target of 7 per cent a year, these benefits were perceived to be substantial.

Years before, in an article in the local newspaper, Mopheme-The Survivor 27 Oct-2 Nov 1998, a writer, Rakoro Phororo, commenting on Prime Minister 
Mosisili's decision to grant to the previous prime minister, Ntsu Mokhehle, a Mercedes Benz in what now appear to have been similar circumstances, wrote:

... in a poor country such as Lesotho, this precedent will ever be the main motive for political leaders to aspire to premiership at all costs, even at the expense of sacrificing principles, conscience, political values, and reconciliation. The dilemma of mediocre political leaders that Lesotho is presently experiencing will thus get worse in the years ahead.

The irony is that Phororo went on to become Minister of Agriculture in the 2002 Cabinet and is now a member of the group which had made the controversial decision.

At a public gathering in March 2006 the prime minister complained about the public outcry over the vehicles, going on to proclaim 'Ketla Ba Busa Ho Fihlela Ba Tloaela. Ea Belelang a eo bollella Khaitseli ea Malom'ae (I will reign on over you until you are accustomed to my premiership. Whoever is in doubt should protest to his uncle).'

It is unfortunate that the government has failed to acknowledge that government property cannot be transferred to individuals in such a manner. The government is not a corporation but a public entity. Government property is normally auctioned publicly and the proceeds channelled to the public purse, not kept for the benefit of individuals in powerful positions. Minister Phororo, lamented in his 1998 article that:

... if I was a leader of a government that is sensitive to human misery and national economic tragedy, such as has befallen Lesotho, I and my colleagues would humbly approach our predecessor [Mokhekhle] and plead with him for us to at least postpone granting of an expensive car until the economic situation improves.

Mopheme-The Survivor 27 Oct-2 Nov1998

Since Phororo wrote the article economic misery in Lesotho has worsened. He was against the granting of one car, yet he has become mute about the allocation of 36 vehicles. He did not suggest the postponement he had so eloquently advocated. He did not even try to persuade his colleagues that what they were doing was wrong.

The vehicle scheme led to the creation of a popular perception which Bratton \& Van de Walle (1997, p 99) equate with that which prevailed in the early 1990s whereby citizens opined that those "with access to political power were living high on the hog while ordinary people suffered'. 
Despite all these factors the LCD defied the odds and won the 2007 elections as it had those in 1998 and 2002. The question remains why. The LCD victory may be explained by borrowing some important aspects from the rational choice model. In his analysis of the RCM Crewe (1993) argued that the model involves three different judgements about political parties. For instance, the issue of unemployment makes voters judge parties by their policies on job creation (policyvoting), by their degree of emphasis on the problem at hand (priority-voting) or by their past record on unemployment (performance-voting).

The LCD was vocal in pointing out that it had been able to relieve the poor by providing pensions and free education (policy). It also placed much emphasis on the proposed increase in the monthly pension (priority) and on the fact that it had created many jobs (performance).

The party exploited every possible means available to increase voters' confidence in the party and to convince the electorate that it was more competent in managing the economy than other parties would be. It would appear that the $\mathrm{ABC}$ and other major opposition parties, like the BNP and the Alliance of Congress Parties (ACP), were not trusted. This was similar to the situation in Britain in 1983 and 1987 when the Labour Party and other alliance parties were defeated by the Conservative Party because they were seen as divided and it was believed that despite their good policies a vote for them was a wasted vote.

The ABC had split from the LCD a mere four months before polling day as a result of intra-party conflict. Similarly, the BNP had fragmented, giving birth to the Basotho Democratic National Party (BDNP), while the ACP was a coalition of former congress parties, one of which had broken away from the LCD. It can be argued, therefore, that voters had no confidence in the leadership of these parties, instead, voting for the party they saw as capable of managing the economy. The LCD also managed to raise voters' expectations that they would be better off under an LCD government because expectations played a significant role in determining the level of support for the government in 2007.

Nevertheless, the rational choice model, like all others, has some problems. It explains very little about class and partisanship alignments and it is theoretical and difficult to apply in practice because of the unpredictable nature of voters' decisions.

The major problem is that it is often hard to ascertain whether particular attitudes cause certain behaviour or whether they are rationalisations. When the rational model is closely scrutinised its case for cause and effect becomes very weak. All that can be assumed is that pocket-book voting might have been responsible for creating conducive conditions for the LCD to win the 2007 general election, but the evidence available has not been compelling enough to justify this conclusion. 
On the other hand, the case of the $\mathrm{ABC}$, even though the issue of hunger was high on its manifesto, does not appear to have translated into a major swing throughout the country, except in Maseru, where it won nine constituencies (IEC 2007). What was significant during this period was that the rise in unemployment to 45 per cent during the term of the Parliament elected in 2002, though it inflicted a small amount of damage on government's electoral fortunes, was not enough to prevent its re-election.

Table 2

Parliamentary By-elections February 2003 to February 2005

\begin{tabular}{|l|c|l|c|c|c|c|}
\hline Constituency & Election date & \multicolumn{1}{|c|}{$\begin{array}{c}\text { Parties } \\
\text { participating }\end{array}$} & $\begin{array}{c}\text { Registered } \\
\text { voters }\end{array}$ & $\begin{array}{c}\text { Total } \\
\text { votes }\end{array}$ & $\begin{array}{c}\text { Voter } \\
\text { turnout }\end{array}$ & Winner \\
\hline Motete & 15 Feb 2003 & $\begin{array}{l}\text { MFP, PFD, } \\
\text { LCD, BAC, } \\
\text { 2 Independents }\end{array}$ & 11768 & 3945 & $34 \%$ & LCD \\
\hline Qhoali & 23 Aug 2003 & $\begin{array}{l}\text { LPC, LCD, PFD, } \\
\text { MFP }\end{array}$ & 10929 & 3516 & $32 \%$ & LCD \\
\hline Khafung & 23 Aug 2003 & $\begin{array}{l}\text { PFD, LCD, LPC, } \\
\text { NIP.LWP, BCP, MFP }\end{array}$ & 11391 & 4280 & $38 \%$ & LCD \\
\hline Thaba-Putsoa & 24 Jan 2004 & $\begin{array}{l}\text { MFP, LCD, PFD, } \\
\text { LWP, UP }\end{array}$ & 13319 & $335325 \%$ & LCD & \\
\hline Motimposo & 24 Apr 2004 & $\begin{array}{l}\text { NIP, BCP, PFD, LCD, } \\
\text { NLFP, MFP, LWP }\end{array}$ & 13125 & 1712 & $13 \%$ & LCD \\
\hline Mohobollo & 5 Jun 2004 & $\begin{array}{l}\text { PFD, MFP, LCD, NIP, } \\
\text { 2 Independents. }\end{array}$ & 9999 & 1690 & $17 \%$ & LCD \\
\hline Qhoali & 16 Oct 2004 & BCP, LCD & 11820 & 3155 & $27 \%$ & LCD \\
\hline Koro-Koro & 12 Feb 2005 & LCD, NIP, PFD & 9186 & 2542 & $28 \%$ & LCD \\
\hline Qalo & 4 Oct 2005 & $\begin{array}{l}\text { LCD, PFD, NIP, } \\
4 \text { Independents }\end{array}$ & 7291 & 856 & $14 \%$ & LCD \\
\hline Lebakeng & 22 Apr 2006 & \begin{tabular}{l} 
LCD \\
\hline
\end{tabular} & & 386 & Unoppossed & LCD \\
\hline
\end{tabular}

Source: Independent Electoral Commission 2003-2006

1 Lesotho's Parliament comprises 10 parties, most of which participated only irregularly in by-elections. Among those which participated are the: National Progressive Party (NPP), Basotholand Congress Party (BCP), Basutoland African Congress (BAC), Marematlou Freedom Party (MFP), LCD, Lesotho Workers' Party (LWP), Popular Front For Democracy (PFD), Lesotho People's Congress (LPC) and National Independent Party (NIP). The major opposition party, the BNP, did not stand in any of these by-elections. Two smaller parties outside Parliament, the United Party (UP) and the New Lesotho Freedom Party (NLFP), participated in by-elections on 24 January 2004 and 24 April 2004 respectively, while eight independent candidates stood in three. 
A party which is likely to win an election is evaluated, particularly during by-elections, on its 'performance or party program' (Peele, Bailey \& Cain 1992, p 64 ) or by the frequency with which it holds government accountable on all fronts. It is fair to assume that the LCD has been able to maintain its momentum by contesting every by-election - constantly reminding its supporters of its existence. Table 2 illustrates the scale of LCD victories in by-elections.

Judging from several by-elections held since 2002 and the recent general election voter participation has declined drastically. The apparent LCD victory in these by-elections, as illustrated in Table 2, reflects the strength of the party's record, a feature which also fits the rational choice model. However, these victories were largely against insignificant opponents since some of the major opposition parties, notably the BNP, boycotted the by-elections. In the 25 April 2005 elections, for instance, the LCD candidate was unopposed.

It is also important to acknowledge that ruling parties have an advantage over opposition parties not only during by-elections but in general elections because of the access to state resources given to them by their incumbency.

Most governments in Africa have been notorious for using state resources to attract short-term benefits such as votes. This practice is more pronounced in countries like Lesotho where the political code of conduct does not make the practice illegal. It has been an open secret in the country, for instance, that, in all the above by-elections, the state paved roads, attended to other development projects and provided food a few weeks before by-elections took place.

It has been this incumbency advantage that has disadvantaged opposition parties, many of whom saw no point in contesting elections in such an environment.

\section{CONCLUSION}

The use of state resources for political legitimacy and the promotion of clientelism has been pervasive in most African countries. There are several aspects of neopatrimonial rule and patron-client relationships being used in Lesotho to solicit votes for the ruling party. However, where this strategy has been practised it has happened on a very small scale, to influence voters to vote for the patron. Furthermore, the policies the ruling party used during the campaign benefited people across the country, even where the LCD lost. This leads to the conclusion that the voters voted on the basis of rational choice rather than sociological or party identification.

While there is a variety of reasons for the LCD victory the rational choice theory appears to come closest to providing a plausible explanation for this victory and illuminating patterns of voting behaviour in the country. 
Although it should not be assumed that the model is problem free criticisms of the flourishing rational choice research programme are not completely without merit, neither are they debilitating. Given the heterogeneity of the political science profession it would be surprising if any one approach won general acceptance. The approach itself is still debated by all scholars and in some cases, such as that of Lesotho, it has been relatively insightful, while in others it provides less than plausible arguments. This paper is therefore, part of the on-going debate about the use of the theory to explain elections.

In conclusion, therefore, I argue that there is evidence to indicate that the RCM applied to the 2007 elections. Most rural voters still believe the LCD is managing the economy more competently than another party might, hence they vote for it on the assumption that they are better off under an LCD administration which advocates pension for the elderly, free education, and economic prosperity.

\section{RECOMMENDATIONS}

From the above it is clear that political parties must mount civic education campaigns to inform people what they should expect from their parties and how to hold them accountable. When the voters know their rights they will vote in a more informed manner. An informed voter is likely to make a sound choice about who to vote for and why. This would entrench democracy in an agrarian society like Lesotho, where voters vote on the basis of patron-client relationships and where the likelihood of making the wrong choices is high.

Secondly, political parties in Lesotho depend heavily on paltry and irregular contributions from members. This means they cannot undertake their party programmes effectively. Financial weakness is one of the main limitations of opposition parties, some of which have cited lack of funds as a reason for nonparticipation in by-elections. ${ }^{2}$

Therefore, it is important for political parties to have access to party funding so they can run their affairs and compete in by-elections, in which, currently, the ruling party appears to be benefiting unfairly from its incumbency.

Without such funding opposition parties are unable to mobilise extensively for any elections. It is necessary to institute legislation dealing with funding and taking account of party representation in Parliament and the percentage of the vote a party has won.

Finally, Lesotho needs a sound political code of conduct which regulates the activities of both the ruling and the opposition parties. Such a code would provide

2 That not withstanding, six opposition parties participated in the Motimposo by-election and they were joined by another, which has no representation in Parliament. Motimposo is the constituency situated within the capital, Maseru, where the leaders of all the political parties reside. 
a level playing field for all contesting parties and ensure that the ruling party does not have an unfair advantage, particularly because it has access to state resources.

\section{- REFERENCES -}

All Basotho Convention. 2007. Election Manifesto. Maseru: ABC NEC.

Barkan, J. 1995. 'Elections in Agrarian Societies'. Journal of Democracy 6.

Bratton, M\& N van de Walle. 1997. Democratic Experiments in Africa: Regime Transitions in Comparative Perspective. Cambridge: Cambridge University Press.

Budge, I \& D McKay. 1993. The Developing British Political System: The 1990s. 3rd ed. London: Longman.

Crewe, I. 1993. 'Voting and the Electorate'. In P Dunleavy, I Holliday \& A Gamble. Developments in British Politics 4. London: Macmillan.

Dearlove, J \& P Saunders. 2000. Introduction to British Politics. 3rd ed. Cambridge: Polity Press.

Denver, D. 1989. Elections And Voting Behaviour in Britain. London: Philip Allen. \& G Hands (eds). 1992. Issues And Controversies in British Voting Behaviour. London: Harvester Wheatsheaf.

Downs, A. 1957. An Economic Theory of Democracy. New York: Harper and Row.

Dunleavy, P \& C T Husbands. 1985. British Democracy at the Crossroads: Voting and Party Competition in the 1980s. London: George Allen \& Unwin.

Dunleavy, P, G Peele \& A Gamble (eds). 1990. Developments In British Politics 3. London: Macmillan.

Dunleavy, P. 1991. Democracy, Bureaucracy and Public Choice: Economic Models in Political Science. London: Pearson.

FAO. 2007. Global Information and Early Warning System on Food and Agriculture World Food Programme. Special Report: Lesotho, 12 June.

Heywood, A.1997. Politics. London: Macmillan Foundations Press.

King, A C, P Norton, D Denver, P Seyd \& I Crewe (eds).1992. Britain at the Polls 1992. New Jersey: Chatham House.

Lesotho Congress for Democracy. 2007. Election Manifesto. Maseru: LCD NEC.

Matlosa, K. 1999. 'Conflict and Conflict Management: Lesotho's Political Crisis After the 1998 Election'. Lesotho Social Science Review 5, 1 June.

Miller, W L (ed). 1990. 'Voting and the Electorate'. In P Dunleavy, G Peele \& A Gamble (eds). Developments in British Politics 3. London: Macmillan.

Mopheme-The Survivor, 27 October-2 November 1998.

Public Eye 27 March 2006.

10 November 2006.

23 February 2007. 
National Assembly Election Act 1992.

Nnoli, O. 1986. Introduction to Politics. Singapore: Longman Singapore Publishers.

Peele G, C J Bailey \& B Cain (eds).1992. Development in American Politics. London: Macmillan.

Rational Choice Theory. Available at en.wikipedia.org/wiki/Rational choice_theory. Randall V \& R Theobald. 1985. Political Change and Underdevelopment: A Critical Introduction to Third World Politics. London: Macmillan.

Sanders, D.1992. 'Why the Conservative Party Won Again'. In A C King, P Norton, D Denver, P Seyd \& ICrewe (eds). Britain at the Polls 1992. New Jersey: Chatham House.

Santho, S, F J Likoti \& C Sello. 2007. The 2007 Elections Facilitation Program for Sustainable Democratic Governance in Lesotho: Reflections and Lesotho. Maseru: Moruo Consultancy.

Thahane, T T. 2007. 'Conducive Investment Climate Essential for Sustainable Economic Growth, Job Creation and Poverty Reduction'. Budget Speech to Parliament for the 2007 / 2008 Fiscal Year. Maseru: Parliament of the Kingdom of Lesotho.

Weingrod, A.1968. 'Patrons, Patronage and Political Parties'. Comparative Studies in Society and History 10, July.

The Government of Lesotho Car Ownership Scheme: An Explanatory Note, 28 August 2006.

Work for Justice October 2006. 